\title{
Spouse Left Home
}

National Cancer Institute

\section{Source}

National Cancer Institute. Spouse Left Home. NCI Thesaurus. Code C150730.

An indication that a married individual who is or was living with another person left their shared home. 